\title{
FERTILIZATION OF PIG FOLLICULAR OOCYTES CULTIVATED IN VITRO
}

\author{
J. MOTLIK AND J. FULKA \\ Czechoslovak Academy of Sciences, Institute of Physiology and Genetics of Farm Animals, \\ Department of Genetics, Liběchov, Czechoslovakia
}

(Received 13th August 1973)

Maturation of primary oocytes in vitro has been described in several species of mammals. Mature pig oocytes can also be obtained in vitro after cultivation in a suitable medium (Edwards, 1965; Foote \& Thibault, 1969; McGaughey \& Polge, 1971; Motlík, 1972). Nuclear changes characteristic of maturation occur in vitro at the same time intervals as they would in vivo after the administration of HCG in vivo (Hunter \& Polge, 1966). A cytogenetic analysis (McGaughey \& Polge, 1971) revealed some anomalies, but these ought not to preclude penetration by spermatozoa and their transformation to pronuclei. Edwards, Bavister \& Steptoe (1969) detected spermatozoa in the cytoplasm of cultivated human oocytes. Mouse oocytes can also be cultivated and fertilized in vitro (Cross \& Brinster, 1970; Mukherjee, 1972), although the fertilization rate is very low. Similar observations after fertilization in vivo have been described in rabbits (Chang, 1955). Little is known about the fertility of artificially matured oocytes from farm animals. The results published on oocytes of the pig (Leman \& Dziuk, 1971) and cow (Hunter, Lawson \& Rowson, 1972) cannot properly be compared, because of the different experimental conditions involved.

It is evident from the above results that the fertility of oocytes cultivated in vitro from the germinal vesicle stage is low. In the present study, we concentrated on the development of the fertility of pig oocytes cultivated from the germinal vesicle, diakinesis and metaphase I stage, respectively. The donors were gilts of the miniature strains Minnesota and Göttingen and crosses of these strains. All the donors were aged 8 to 10 months. Some of the oocytes were taken from the ovaries of untreated gilts, others were removed 80 to $96 \mathrm{hr}$ after the gilts had received 500 i.u. PMSG (Antex, Leo, Copenhagen) on the 15 th day of the cycle. The stage of development of the oocytes was assessed from the onset of oestrus, which was checked for twice daily with a boar. An incision was made in the linea alba 5 to $20 \mathrm{hr}$ later and unilateral ovariectomy was performed. The oocytes in the contralateral ovary, after ovulation, served as controls. Oocytes from the excised ovaries were recovered by perforating the clear wall of growing follicles of the same size depending on the stage of oestrus. After threefold washing, all the oocytes, apart from the controls, were cultivated without selection under conditions described by Motlík (1972) and in medium prepared according to the method of Pavlok \& McLaren (1972), with the exception that freeze-dried bovine serum albumin was replaced by calf serum 
protein $(30 \mathrm{mg} / \mathrm{ml})$. The oocytes were incubated in $0.1 \mathrm{ml}$ medium under paraffin oil at $38^{\circ} \mathrm{C}$ in $5 \% \mathrm{CO}^{2}$ in air. The cultivation time was 8 to 10,13 to 18 or 20 to $27 \mathrm{hr}$, according to the stage of development of the oocytes, one or two of which were fixed and evaluated immediately after recovery. The gilts were mated before ovariectomy and again before transplantation of the oocytes, all of the gilts being still in oestrus. After cultivation, the oocytes were returned surgically to the ampullae of the oviducts belonging to the excised ovaries. One oocyte served as a control for the stage of maturation. At the end of the cultivation period, oocytes were mostly in metaphase II. The gilts were killed 18 to $24 \mathrm{hr}$ after transplantation and the oocytes were flushed from the oviducts, fixed with acetic alcohol, stained with orcein and examined in a phase-contrast microscope. The presence of pronuclei, with a clearly discernible sperm tail in the cytoplasm near one of them, syngamy or cleavage, with nuclear

Table 1. Fertilization rate of pig oocytes cultivated in vitro

\begin{tabular}{|c|c|c|c|c|c|c|c|}
\hline \multirow[b]{2}{*}{$\begin{array}{c}\text { Stage of } \\
\text { meiosis }\end{array}$} & \multirow{2}{*}{$\begin{array}{l}\text { Cultiva- } \\
\text { tion time } \\
\quad(h r)\end{array}$} & \multirow[b]{2}{*}{$\begin{array}{c}\text { No. of } \\
\text { gilts }\end{array}$} & \multicolumn{3}{|c|}{ Cultivated oocytes } & \multicolumn{2}{|c|}{ Ovulated oocytes } \\
\hline & & & $\begin{array}{l}\text { Trans- } \\
\text { ferred }\end{array}$ & $\begin{array}{c}R e- \\
\text { covered }\end{array}$ & $\begin{array}{l}\text { Stage after sperm } \\
\text { penetration }(\%)\end{array}$ & $\begin{array}{c}R e- \\
\text { covered }\end{array}$ & \begin{tabular}{|l|} 
Stage after sperm \\
penetration $(\%)$
\end{tabular} \\
\hline $\begin{array}{l}\text { Germinal } \\
\text { vesicle }\end{array}$ & 20 to 27 & 17 & 81 & 63 & $\begin{array}{ccc}20^{*} & 30 \dagger & 3 \div \\
(31 \cdot 7) & (47 \cdot 6) & (4 \cdot 7)\end{array}$ & 46 & $\begin{array}{lc}38^{*} & 2 \ddagger \\
(82 \cdot 6) & (4 \cdot 3)\end{array}$ \\
\hline Diakinesis & 13 to 18 & 14 & 77 & 60 & $\begin{array}{cc}31^{*} & 6 \dagger \\
(51 \cdot 6) & (10)\end{array}$ & 67 & $\begin{array}{cc}52 * & 5 \ddagger \\
(77 \cdot 6),(7 \cdot 4)\end{array}$ \\
\hline Metaphase I & 8 to 10 & 13 & 58 & 46 & $\begin{array}{c}36^{*} \\
(78-2)\end{array}$ & 42 & $\begin{array}{l}38^{*} \\
(90 \cdot 4)\end{array}$ \\
\hline
\end{tabular}

* Normal development of pronuclei or cleavage.

$\uparrow$ Arrested development of male pronuclei ( $32.3 \%$ of ova penetrated by more than one spermatozoon).

$\$$ Polyspermy with normal pronuclei.

material in both blastomeres, were taken as the criteria of fertilization and normal development. The polar bodies are not always clearly observed when other criteria of fertilization were fulfilled.

The results (Table 1) showed an increase in the fertilization rate of the oocytes which correlated with the stage of development at the beginning of cultivation. In oocytes cultivated from the germinal vesicle stage, the fertilization rate was $31.7 \%$; for those taken in diakinesis, it was $51.6 \%$ and for oocytes cultivated from metaphase I, it was $78.2 \%$, i.e. a level almost comparable with naturally maturing germ cells. The principal abnormal form of fertilization encountered was a failure of the head of the spermatozoon to transform to a male pronucleus. Instead, a clearly staining structure composed of randomly organized clumps of chromatin (Pl. 1, Fig. 1, detail in Pl. 1, Fig. 2) appeared near the female pronucleus (Pl. 1, Fig. 3).

An incidence of similar anomalies in formation of the male pronucleus was seldom observed in other species and they were frequent only in the fertilization of cultivated (Thibault \& Gérard, 1970) and cold-activated (Chalmel, 1962) rabbit oocytes. A normal incidence of disturbances of development of the male pronucleus was described in mouse oocytes recovered from ovaries and inseminated before the formation of metaphase I (Iwamatsu \& Chang, 1972). 
PI.ATE 1
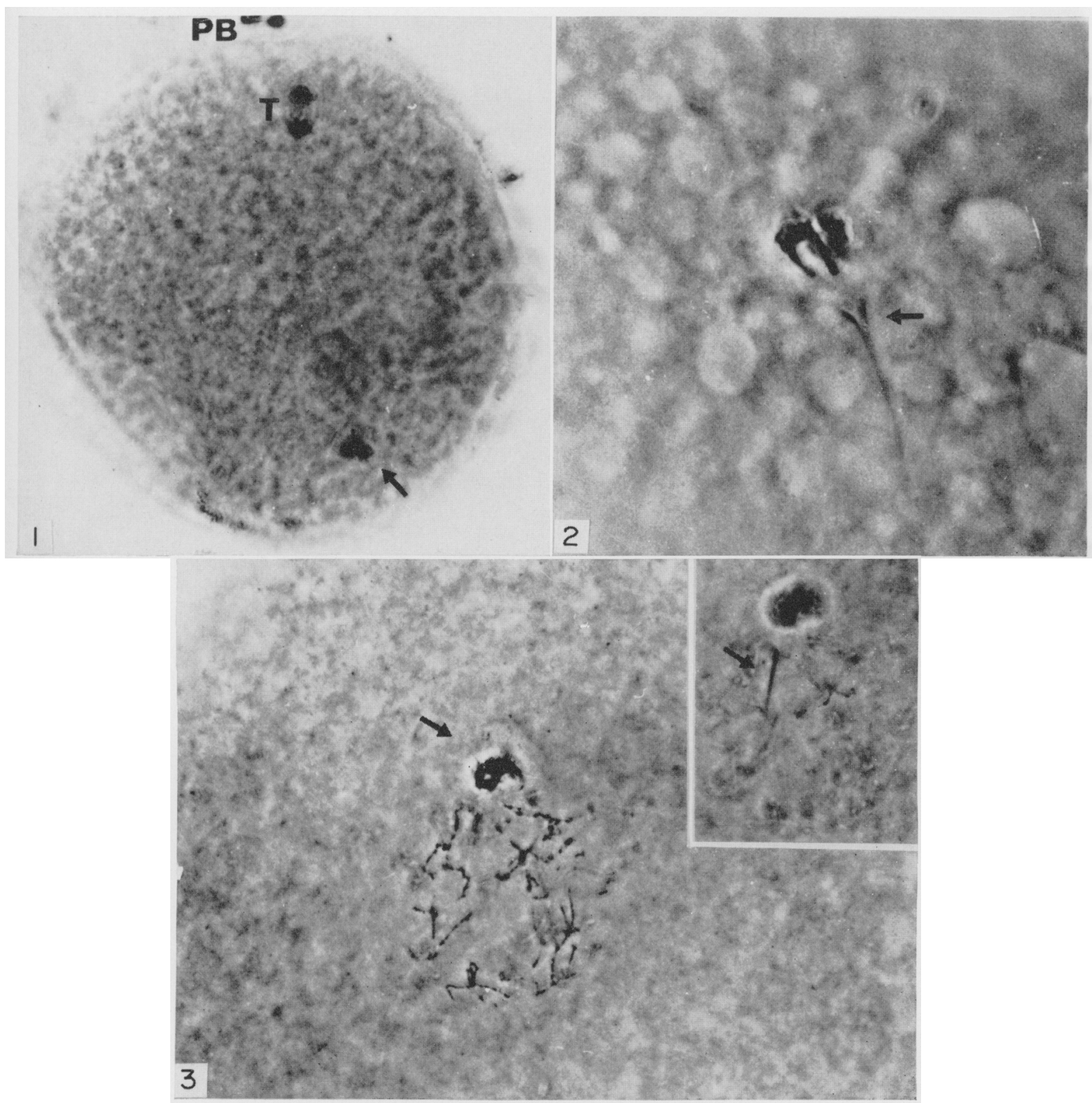

lis. 1. Pig oocyte cultivated for $24 \mathrm{hr}$ and obtained $18 \mathrm{hr}$ after transplantation. 'l'elophase of the second meiotic division ( $\mathrm{C}$ ). the first polar body (P'B) and the sperm head (arrow) are visible. Approx. $\times 450$.

Fic. 2. Detail of the penetrating spermatozoon. Note the condensed chromatin and the split of the mid-piece (arrow). Approx. $\times 1400$.

Fic. 3. Pig oocyte cultivated for $24 \mathrm{hr}$ and obtained $18 \mathrm{hr}$ after transplantation showing the sperm head (arrow) attached to the female pronucleus. In the inset, the same sperma$10 \% 00 n$ is shown at a different foral level with a visible tail (arrow). Approx. $\times 800$. 
This led to the suggestion that incorporation of material from the germinal vesicle into the oocyte cytoplasm is needed to make the latter capable of assuring transformation of the head of the spermatozoon to a male pronucleus. Since development progressed to complete nuclear maturation in our experiments, it can be assumed that substances from the germinal vesicle were incorporated into the cytoplasm of the pig oocyte. Despite this, in most cases the head of the spermatozoon was not transformed to a male pronucleus, but was simply reduced to condensed chromatin (compact or variously fragmented). Both male and female pronuclei developed in only $43.3 \%$ of the penetrated oocytes cultivated from the germinal vesicle stage. A detailed study of the germinal vesicle in association with changes of 'diffuse' to 'fibrous' chromatin might help to furnish an explanation. These anomalies were rare in oocytes cultivated from the diakinesis stage and in later stages they were not observed at all. The incidence of polyspermy was approximately the same in cultivated and spontaneously ovulated oocytes in which development of the pronuclei was normal (Table 1). It occurred in almost a third of the oocytes with the above developmental anomaly. It can be concluded that the given cultivation method allows maturation of the nuclear component but that for oocytes in the initial stages of development, it does not provide the natural intrafollicular medium to the extent required for normal development of the cytoplasm.

\section{REFERENGES}

Chalmel, M. C. (1962) Possibilité de fécondation des oeufs de lapine activés parthénogénétiquement. Annls Biol. anim. Biochim. Biophys. 2, 279.

Ghang, M. G. (1955) The maturation of rabbit oocytes in culture and their maturation, activation, fertilization and subsequent development in the Fallopian tubes. F. exp. Zool. 128, 379.

Cross, P. C. \& Brinster, R. L. (1970) In vitro development of mouse oocytes. Biol. Reprod. 3, 298.

EDWARDS, R. G. (1965) Maturation in vitro of mouse, sheep, cow, pig, Rhesus monkey and human ovarian oocytes. Nature, Lond. 208, 349.

Edwards, R. G., Bavister, B. D. \& Steptoe, P. G. (1969) Early stages of fertilization in vitro of human oocytes matured in vitro. Nature, Lond. 221, 632.

Foote, W. D. \& Thibault, G. (1969) Recherches expérimentales sur la maturation in vitro des ovocytes de truie et de veau. Annls Biol. anim. Biochim. Biophys. 9, 329.

Hunter, R. H. F., Lawson, R. A. S. \& Rowson, L. E. A. (1972) Maturation, transplantation and fertilization of ovarian oocytes in cattle. 7. Reprod. Fert. 30, 325.

Hunter, R. H. F. \& Polge, C. (1966) Maturation of follicular oocytes in the pig after injection of human chorionic gonadotrophin. F. Reprod. Fert. 12, 525.

Iwamatsu, T. \& Chang, M. C. (1972) Sperm penetration in vitro of mouse oocytes at various times during maturation. F. Reprod. Fert. 31, 237.

Leman, A. D. \& Dzıuk, P. J. (1971) Fertilization and development of pig follicular oocytes. J. Reprod. Fert. 26, 387.

McGaughey, R. W. \& Polge, G. (1971) Gytogenetic analysis of pig oocytes matured in vitro. 7. exp. Zool. 176, 383.

Motıík, J. (1972) Cultivation of pig oocytes in vitro. Folia biol., Praha, 18, 345.

MukHERJEe, A. B. (1972) Normal progeny from fertilization in vitro of mouse oocytes matured in culture and spermatozoa capacitated in vitro. Nature, Lond. 237, 397.

Pavlok, A. \& McLaren, A. (1972) The rôle of cumulus cells and the zona pellucida in fertilization of mouse eggs in vitro. 7 . Reprod. Fert. 29, 91.

Thibault, G. \& GÉRARd, M. (1970) Facteur cytoplasmique nécessaire à la formation du pronucleus mâle dans l'ovocyte de lapine. C.r. hebd. Séanc. Acad. Sci., Paris, Série D, 270, 2025. 